\title{
Pengaruh Pemberian Limbah Jintan Hitam (Nigella sativa) dalam Ransum Terhadap Deposisi Lemak Ayam Broiler
}

\author{
The Effect of Providing Black Cumin (Nigella sativa) Waste in a Ration on Deposition of \\ Broiler Chicken Fat
}

\author{
J. M. Pasaribu, I. Badarina, dan Kususiyah \\ Jurusan Peternakan Fakultas Pertanian Universitas Bengkulu \\ Jalan Raya W. R. Supratman, Kandang Limun, Bengkulu, 38371A \\ Corresponding e-mail : jesikamariatipasaribu@gmail.com
}

\begin{abstract}
This study aimed to evaluate the effect of giving black cumin waste (Nigella sativa) in the ration against broiler fat deposition. This research was conducted from December to January 2016 in the laboratory and enclosure of the Department of Animal Husbandry, Faculty of Agriculture, University of Bengkulu. This study used 80 broiler chickens with a Completely Randomized Design (CRD) of 5 treatments and 4 replications, namely P0 as a control (without administration of black cumin waste in the ration), P1 (giving $0.5 \%$ black cumin waste in the ration), P2 (giving 1\% black cumin waste in rations), P3 (giving 1.5\% black cumin waste in rations), P4 (giving $2 \%$ black cumin waste in the ration). The variables observed were the percentage of abdominal fat, percentage of gizzard fat, percentage of neck fat, percentage of sartorial fat. The results of this study indicate that the administration of black cumin waste in the ration had no significant effect $(\mathrm{P}>0.05)$ on broiler fat deposition. Abdominal fat percentage ranged from $0.85 \%-1.16 \%$, the percentage of gizzard fat ranged from $0.61 \%-0.85 \%$, the percentage of neck fat ranged from $0.03 \%-0.05 \%$, the percentage of sartorial fat ranged from $0.48 \%-0.58 \%$. It was concluded that the administration of black cumin waste to the level of $2 \%$ could not reduce fat deposition of broiler chickens.
\end{abstract}

Key words: Black cumin waste, broiler chicken, fat deposition

\begin{abstract}
ABSTRAK
Penelitian ini bertujuan untuk mengevaluasi pengaruh pemberian limbah jintan hitam (Nigella sativa) dalam ransum terhadap deposisi lemak ayam broiler. Penelitian ini dilaksanakan mulai bulan Desember sampai bulan Januari 2016 di laboratorium dan kandang Jurusan Peternakan Fakultas Pertanian Universitas Bengkulu. Penelitian ini menggunakan 80 ekor ayam broiler dengan Rancangan Acak Lengkap (RAL) 5 perlakuan dan 4 ulangan yaitu P0 sebagai kontrol (tanpa pemberian limbah jintan hitam dalam ransum), P1 (pemberian 0,5\% limbah jintan hitam dalam ransum), P2 (pemberian $1 \%$ limbah jintan hitam dalam ransum), P3 (pemberian 1,5 $\%$ limbah jintan hitam dalam ransum), P4 (pemberian $2 \%$ limbah jintan hitam dalam ransum). Variabel yang diamati adalah persentase lemak abdomen, persentase lemak gizzard, persentase lemak leher, persentase lemak sartorial. Hasil penelitian ini menunjukkan bahwa pemberian limbah jintan hitam dalam ransum berpengaruh tidak nyata $(\mathrm{P}>0,05)$ terhadap deposisi lemak ayam broiler. Persentase lemak abdomen berkisar $0,85 \%-1,16 \%$, persentase lemak gizzard berkisar $0,61 \%-0,85 \%$, persentase lemak leher berkisar $0,03 \%-0,05 \%$, persentase lemak sartorial berkisar 0,48\%-0,58\%. Disimpulkan bahwa pemberian limbah jintan hitam sampai level 2\% tidak dapat menurunkan deposisi lemak ayam broiler.
\end{abstract}

Kata Kunci : Limbah jintan hitam, ayam broiler, deposisi lemak

\section{PENDAHULUAN}

$\begin{array}{ccr}\text { Pertumbuhan yang cepat pada ayam } \\ \text { broiler } & \text { sering diikuti } & \text { dengan }\end{array}$

peningkatandeposisi lemak yang tinggi, yang akan menjadi masalah bagi konsumen yang menginginkan daging berkualitas baik. Tingginya deposisi lemak pada bagian tubuh ayam broiler mengurangi tingkat keuntungan produsen karena harga pada bagian lemak lebih murah dari pada karkas. Deposisi lemak pada broiler antara lain terjadi di abdomen, gizzard, jantung, leher dan paha. Menurut Bidura et al. (2010) tingginya deposisi lemak pada abdomen berkorelasi positif dengan tingginya kadar lemak tubuh broiler. 
Salah satu upaya untuk mengurangi deposisi lemak adalah dengan pemberian tanaman obat-obatan tradisional. Pemberian tanaman obat-obatan tradisional selain berkhasiat untuk manusia, juga efektif dalam menurunkan deposisi lemak ayam broiler. Salah satu tanaman obat tersebut adalah jintan hitam (Habi et al., 2014).

Nigella sativa atau yang dikenal dengan nama jintan hitam adalah tanaman herbal yang berasal dari daerah di sekitar Laut Mediterania (Rouhou et al., 2007). Jintan hitam kaya akan asam lemak tak jenuh ganda, sangat berperan penting untuk kesehatan manusia. Jintan hitam membantu mengatur metabolisme, membawa racun ke permukaan kulit untuk dieliminasi, menyeimbangkan tingkat insulin, mengatur kolesterol, meningkatkan sirkulasi tubuh dan meningkatkan fungsi hati yang sehat (Salama, 2010).

Pengolahan jintan hitam yang diperoleh pada hasil akhir berupa minyak dan limbah. Minyak jintan hitam digunakan untuk kebutuhan manusia sedangkan untuk limbah belum dimanfaatkan oleh pihak industri rumah tangga yang mengolah biji jintan tersebut. Limbah jintan diperoleh dari salah satu industri rumah tangga pengolah minyak herbal Habbatussauda yang terdapat di Jakarta. Bentuk dari limbah itu sendiri berbentuk serpihan.

Limbah Jintan hitam mengandung bahan kering $92 \%$, bahan organik 90,4\%, protein kasar 33,8\%, serat kasar 5,2\%, lemak $14,2 \%$, energi $2691 \mathrm{Kkal} / \mathrm{kg}$ (El-Nattat dan El-Kady, 2007). Kandungan asam amino esensial limbah jintan hitam (Nigela sativa) yaitu threonin $1,45 \%$, valine $0,04 \%$, methionine $0,55 \%$, isoleucine $1,42 \%$, leucine $2,44 \%$, phenylalanine $1,69 \%$, histidine $1,42 \%$, lysine $1,48 \%$, arginine $3,24 \%$, dan untuk kandungan asam amino nonesensial yaitu aspartic acid 2,97\%, serine 1,35\%, glutamic acid $6,22 \%$, glysine $1,28 \%$, alanine $1,74 \%$, cystine $5,28 \%$, tyrosine $1,69 \%$ (ElRahman et al.,2011).

Penggunaan jintan hitam pada itik hibrida dapat menurunkan kadar lemak abdomen. Habi et al. (2014) mendapatkan itik hibrida dengan pemberian $2 \%$ tepung jintan hitam adalah terendah $(0,93 \%)$, pemberian $1,5 \%$ memperoleh $0,95 \%$, pada pemberian $1 \%$ memperoleh hasil $0,96 \%$ dan pada pemberian $0,5 \%$ memperoleh $0,96 \%$. Berdasarkan uraian tersebut penulis melakukan penelitian lebih lanjut tentang pengaruh pemberian limbah jintan hitam terhadap deposisi lemak ayam broiler. Penelitian ini bertujuan untuk mengevaluasi pengaruh pemberian limbah jintan hitam terhadap deposisi lemak ayam broiler. Pemberian limbah jintan hitam diduga dapat menurunkan deposisi lemak ayam broiler.

\section{MATERI DAN METODE}

Penelitian ini dilaksanakan pada bulan Desember sampai bulan Januari 2016 di Laboratorium dan kandang Jurusan Peternakan Fakultas Pertanian Universitas Bengkulu.

Alat yang digunakan dalam penelitian ini adalah 20 petak kandang ayam dengan alas litter masing-masing berukuran $90 \mathrm{~cm}$ x 90 $\mathrm{cm}$ x $60 \mathrm{~cm}$, timbangan analitik, lampu, ember, alat pemanas, alat penggiling, pisau, talenan, tempat pakan sesuai kebutuhan, alat tulis untuk mencatat data serta peralatan lainnya yang dibutuhkan. Adapun bahan yang digunakan dalam penelitian ini antara lain ayam broiler sebanyak 80 ekor (DOC), pakan yang digunakan yaitu ransum untuk umur ayam mulai DOC sampai 14 hari memakai pakan BR-1, setelah umur ayam 15 hari ayam diberi pakan campuran jagung giling, dedak padi, bungkil kedelai, tepung ikan, mineral mix, top mix, minyak, dan limbah jintan hitam.

\section{Persiapan kandang}

Kandang yang digunakan dalam penelitian ini dibuat petak-petak ukuran 90 $\mathrm{cm}$ x $90 \mathrm{~cm}$ x $60 \mathrm{~cm}$. Jumlah petakan yang digunakan dalam penelitian ini adalah sebanyak 20 petak. Setiap petak dilengkapi dengan tempat pakan dan air minum. Sebelum penelitian dilakukan semua peralatan yang digunakan dibersihkan dan disemprot menggunakan desinfektan sebanyak dua kali. 


\section{Persiapan Ransum}

tersebut homogen. Tabel 1. Menjelaskan Limbah jintan yang berbentuk kandungan nutrisi bahan pakan penyusun serpihan digiling. Semua bahan pakan yang ransum yang digunakan.

digunakan dicampur hingga bahan pakan

Tabel 1. Kandungan nutrisi bahan pakan penyusun ransum

\begin{tabular}{lcccccc}
\hline Bahan Pakan & $\begin{array}{c}\text { Lemak } \\
(\%)\end{array}$ & $\begin{array}{c}\text { Serat } \\
\text { kasar } \\
(\%)\end{array}$ & $\begin{array}{c}\text { Protein } \\
(\%)\end{array}$ & $\begin{array}{c}\text { Energi } \\
(\mathrm{kkal} / \mathrm{kg})\end{array}$ & $\begin{array}{c}\text { Ca } \\
(\%)\end{array}$ & $\begin{array}{c}\mathrm{P} \\
(\%)\end{array}$ \\
\hline Bungkil kedelai* & 4,9 & 5,3 & 41,3 & 2616 & 0,24 & 0,57 \\
Jagung giling* & 4 & 2,2 & 8,9 & 3321 & 0,02 & 0,23 \\
Dedak padi* & 12,1 & 10 & 11,9 & 2400 & 0,1 & 1,3 \\
Tepung ikan* & 6,8 & 2,2 & 52,6 & 2900 & 5,68 & 3,73 \\
Limbah jintan hitam** & 5,16 & 22,48 & 29,92 & 2206 & 1,28 & 0,68 \\
Mineral mix* & 0 & 0 & 0 & 0 & 32 & 10 \\
Top mix* & 0 & 0 & 0 & 0 & 0 & 0 \\
Minyak* & 0 & 0 & 0 & 9800 & 0 & 0 \\
\hline
\end{tabular}

Ket : * Hartadi et al. (2005); **Hasil analisa IPB (2012)

Tabel 2. Komposisi ransum penelitian

\begin{tabular}{lccccc}
\hline \multirow{2}{*}{ Bahan Pakan } & \multicolumn{5}{c}{ Perlakuan } \\
\cline { 2 - 6 } & P0 & P1 & P2 & P3 & P4 \\
\hline Bungkil kedelai (\%) & 26 & 26 & 26 & 26 & 26 \\
Jagung giling (\%) & 55 & 55 & 54,5 & 54,5 & 54 \\
Dedak padi (\%) & 10 & 10 & 10 & 9,5 & 9,5 \\
Tepung ikan (\%) & 5 & 5 & 5 & 5 & 5 \\
Limbah jintan hitam (\%) & 0 & 0,5 & 1 & 1,5 & 2 \\
Mineral mix (\%) & 2,5 & 2,5 & 2,5 & 2,5 & 2,5 \\
Top mix (\%) & 0,5 & 0 & 0 & 0 & 0 \\
Minyak (\%) & 1 & 1 & 1 & 1 & 1 \\
\hline Total (\%) & 100 & 100 & 100 & 100 & 100 \\
\hline
\end{tabular}

Tabel 3. Kandungan nutrisi ransum penelitian

\begin{tabular}{lccccc}
\hline \multirow{2}{*}{ Kandungan nutrisi } & \multicolumn{5}{c}{ Perlakuan } \\
\cline { 2 - 6 } & P0 & P1 & P2 & P3 & P4 \\
\hline Protein kasar (\%) & 19,45 & 19,60 & 19,70 & 19,79 & 19,90 \\
Energi (kkal/kg) & 2989,71 & 3000,74 & 2995,16 & 2995,00 & 2988,62 \\
Serat kasar (\%) & 3,70 & 3,81 & 3,91 & 3,97 & 4,08 \\
Lemak (\%) & 5,02 & 5,04 & 5,05 & 5,02 & 5,02 \\
$\mathrm{Ca}(\%)$ & 1,16 & 1,17 & 1,18 & 1,18 & 1,19 \\
$\mathrm{P}(\%)$ & 0,84 & 0,84 & 0,84 & 0,83 & 0,84 \\
\hline
\end{tabular}




\section{Pelaksanaan Penelitian}

DOC yang baru tiba segera dikeluarkan dari boks kemudian diberi air gula untuk mengurangi stress dalam perjalanan. DOC pada umur 0-2 minggu dipelihara bersama pada kandang brooding. Setelah berumur 2 minggu sebanyak 80 ekor ditempatkan secara acak kedalam 20 petak kandang, setiap kandang diisi 4 ekor ayam broiler. Ayam broiler dipelihara dalam kandang litter sampai berumur 35 hari. Pemeliharaan ayam broiler dilakukan sesuai dengan standar pemeliharaan yang berlaku. Jumlah ransum yang dikonsumsi,konversi ransum, dan pertambahan berat badan diukur setiap minggu. Vaksinasi ND dilakukan pada saat broiler berumur 4 hari melalui tetes mata dan pada saat broiler berumur 21 hari,dilakukan vaksinasi ulang melalui air minum.

\section{Rancangan Percobaan}

Penelitian ini menggunakan

Rancangan Acak Lengkap (RAL), dengan 5 perlakuan dengan 4 ulangan dan setiap ulangan terdiri dari 4 ekor ayam. Kelima perlakuan tersebut adalah sebagai berikut :

P0 : Tanpa pemberian limbah jintan hitam dalam ransum

P1 : Pemberian 0,5\% limbah jintan hitam

P2 : Pemberian $1 \%$ limbah jintan hitam

P3 : Pemberian 1,5\% limbah jintan hitam

P4 : Pemberian $2 \%$ limbah jintan hitam

Model matematika yang digunakan dalam rancangan ini adalah :

$$
Y i j=\mu+\alpha i+e i j
$$

Keterangan :

Yij : Nilai pengamatan perlakuan ke-i dan ulangan ke-j

$\mu \quad$ : Nilai rataan umum

ai : Pengaruh perlakuan ke-i

eij : Pengaruh galat percobaan

i : Perlakuan $(1,2,3,4,5)$

j : Ulangan $(1,2,3,4)$

\section{Pengambilan Data}

Pengambilan data dilakukan setelah broiler berumur 35 hari. Broiler yang berasal dari masing-masing petak diambil secara acak sebanyak 1 ekor kemudian disembelih. Sebelum penyembelihan dilakukan, ayam dipuasakan selama 12 jam.Penimbangan dilakukan terhadap berat badan, lemak abdomen, lemak gizzard, lemak sartorial dan lemak leher.

\section{Variabel dan Analisis Data}

\section{Lemak Abdomen}

Lemak abdomen diperoleh dengan menimbang lemak yang menempel pada rongga perut dari dasar kloaka hingga bagian yang melekat pada gizzard. Persentase lemak abdomen dihitung dengan rumus sebagai berikut :

Lemak Abdomen $(\%)=\frac{\text { Berat Lemak Abdomen }}{\text { Berat Badan }} \times 100 \%$

\section{Lemak Gizzard}

Lemak gizzard diperoleh dengan menimbang lemak yang menempel pada gizzard. Lemak ini dipersentasekan terhadap berat badan ayam. Persentase lemak gizzard dihitung dengan rumus sebagai berikut :

$$
\text { Lemak Gizzard }(\%)=\frac{\text { Berat Lemak Gizzard }}{\text { Berat Badan }} \times 100 \%
$$

\section{Lemak Leher}

Lemak leher adalah lemak yang menempel di bagian leher ayam. Lemak ini dipersentasekan terhadap berat badan ayam.Persentase lemak leher dihitung dengan rumus sebagai berikut :

$$
\text { Lemak Leher }(\%)=\frac{\text { Berat Lemak Leher }}{\text { Berat Badan }} \times 100 \%
$$

\section{Lemak Sartorial}

Lemak sartorial adalah lemak yang berada di paha ayam. Lemak ini dipersentasekan terhadap berat badan ayam. Persentase lemak sartorial dihitung dengan rumus sebagai berikut:

$$
\text { Lemak Sartorial }(\%)=\frac{\text { Berat Lemak Sartorial }}{\text { Berat Badan }} \times 100 \%
$$




\section{Analisis Data}

Data yang diperoleh dianalisis dengan sidik ragam (ANOVA), bila perlakuan berpengaruh nyata $(\mathrm{P}<0,05)$ dilakukan uji lanjut dengan menggunakan Duncan's Multiple Range Test (DMRT) untuk melihat perbedaan antar perlakuan (Steel and Torrie,1993).

\section{HASIL DAN PEMBAHASAN}

Pengaruh pemberian limbah jintan hitam terhadap lemak abdomen, lemak gizzard, lemak leher, lemak sartorial selama penelitian disajikan pada Tabel 4 .

\section{Pengaruh pemberian limbah jintan hitam terhadap persentase lemak abdomen}

Hasil analisis ragam menunjukkan bahwa perlakuan pemberian limbah jintan hitam berpengaruh tidak nyata $(\mathrm{P}>0,05)$ terhadap lemak abdomen ayam broiler. Hal ini menunjukkan bahwa limbah jintan hitam tidak menurunkan lemak abdomen ayam broiler. Hasil penelitian Salam (2013) menyatakan bahwalemak abdominal ayam broiler yang diberi tepung jintan hitam (Nigella sativa) dalam ransum selama musim panas, tidak dapat mengurangi deposit lemak abdomen. Berbeda dengan hasil penelitian yang dilakukan Habi et al. (2014) menyatakan bahwa pemberian tepung jintan hitam 2\% pakan memberikan perbedaan pengaruh yang sangat nyata $(\mathrm{P}<0,01)$ menurunkan persentase lemak abdominal itik hibrida berkisar 0,93\% - 0,97\%. Lebih lanjut Habi et al. (2014) menyatakan jintan hitam dapat membantu menurunkan berat badan secara alami dan tanpa efek samping, karena jintan hitam bekerja membantu menghambat penyerapan lemak. Menurut Fontana et al. (1993) lemak abdomen akan meningkat pada ayam yang diberi ransum dengan protein rendah dan energi ransum yang tinggi. Energi yang berlebih akan disimpan dalam bentuk lemak dalam jaringan-jaringan. Salah satu bagian tubuh yang digunakan untuk menyimpan lemak oleh ayam adalah bagian sekitar perut (abdomen).

Genotif, jenis kelamin, dan nutrisi dari ayam broiler merupakan beberapa faktor yang mempengaruhi deposisi lemak tubuh (Tumova dan Teimouri, 2010). Kisaran lemak abdomen yang didapatkan dalam penelitian ini berkisar antara $0,85 \%-1,16 \%$. Sandi et al. (2012) mendapatkan persentase lemak abdomen broiler berkisar antara 1,21\% - 1,41\%. Menurut North (1984) kandungan lemak abdominal pada ayam broiler jantan umur 6 minggu adalah 2,62\%, sedangkan ayam broiler betina umur 6 minggu yaitu $3,05 \%$ dan dari $60 \%$ total lemak abdomen berupa bantalan lemak.

Tabel 4. Pengaruh limbah jintan hitam terhadap lemak abdomen, lemak gizzard, lemak leher dan lemak sartorial.

\begin{tabular}{lllll}
\hline Perlakuan & Lemak abdomen & Lemak gizzard & Lemak leher & Lemak sartorial \\
\hline & & \multicolumn{2}{c}{$\ldots . . \%$} \\
P0 & $0,85 \pm 0,14$ & $0,76 \pm 0,24$ & $0,05 \pm 0,02$ & $0,58 \pm 0,21$ \\
P1 & $1,02 \pm 0,31$ & $0,70 \pm 0,13$ & $0,04 \pm 0,02$ & $0,48 \pm 0,17$ \\
P2 & $1,10 \pm 0,47$ & $0,61 \pm 0,20$ & $0,03 \pm 0,01$ & $0,57 \pm 0,16$ \\
P3 & $0,96 \pm 0,12$ & $0,85 \pm 0,20$ & $0,04 \pm 0,01$ & $0,58 \pm 0,14$ \\
P4 & $1,16 \pm 0,36$ & $0,81 \pm 0,27$ & $0,04 \pm 0,01$ & $0,57 \pm 0,15$ \\
Probabilitas & $0,67 \mathrm{~ns}$ & $0,56 \mathrm{~ns}$ & $0,39 \mathrm{~ns}$ & $0,88 \mathrm{~ns}$ \\
\hline
\end{tabular}

Keterangan : $\quad n s$ : berpengaruh tidak nyata $(\mathrm{P}>0,05)$

P0 : kontrol, tanpa limbah jintan hitam

P1 : 0,5\% limbah jintan hitam

P2 : 1\% limbah jintan hitam

P3 : 1,5\% limbah jintan hitam

P4 : 2\% limbah jintan hitam 


\section{Pengaruh Pemberian Limbah Jintan Hitam terhadap Persentase Lemak Gizzard}

Hasil analisis ragam menunjukkan bahwa perlakuan pemberian limbah jintan hitam berpengaruh tidak nyata $(\mathrm{P}>0,05)$ terhadap lemak gizzard ayam broiler. Hal ini menunjukkan bahwa limbah jintan hitam tidak mampu menurunkan lemak gizzard ayam broiler. Persentase lemak gizzard yang diperoleh adalah $0,61 \%$ - 0,85\%, kisaran lemak gizzard ini bila dibandingkan hasil penelitian Faber (2010) tentang penggunaan ekstrak alang-alang (Imperata cylindrical) pada broiler adalah lebih rendah yaitu $0,90 \%$ - 1,28\%. Berbeda lagi dengan penelitian Rusydan (2008) tentang pengaruh penggunaan tepung akar alang-alang (Imperata cylindrical) terhadap penimbunan lemak pada broiler yang mendapatkan persentase lemak gizzard berkisar antara $0,48 \%-0,68 \%$.

Sutrisna et al. (2001) menjelaskan tentang penambahan serbuk gergaji kayu, ragi tape serta kombinasinya dalam ransum basal terhadap distribusi lemak tubuh ayam pedaging menyatakan bahwa berat lemak gizzard 0,65 dari berat hidup ayam broiler pada umur 42 hari. Perbedaan persentase lemak gizzard dari berbagai penelitian ini disebabkan oleh perbedaan perlakuan dan juga umur potong, dan hasil-hasil penelitian ini berpengaruh tidak nyata terhadap setiap perlakuan yang diberikan. Hal ini menunjukkan bahwa pemberian limbah jintan hitam dalam ransum ayam broiler belum mampu menurunkan lemak gizzard pada ayam broiler.

\section{Pengaruh pemberian limbah jintan hitam terhadap persentase lemak leher}

Hasil analisis ragam menunjukkan bahwa perlakuan pemberian limbah jintan hitam berpengaruh tidak nyata $(\mathrm{P}>0,05)$ terhadap lemak leher ayam broiler. Hal ini menunjukkan bahwa limbah jintan hitam tidak dapat menurunkan lemak leher ayam broiler. Persentase lemak leher yang diperoleh berkisar antara 0,03\% - 0,05\%. Kisaran lemak leher ini bila dibandingkan dengan hasil penelitian Putra (2014) tentang pengaruh pemberian fermentasi tepung kulit pisang jantan dengan menggunakan (Neurospora crassa) terhadap deposisi lemak ayam broiler mendapatkan persentase lemak leher adalah 0,07\%- $0,08 \%$ adalah lebih rendah, demikian juga bila dibandingkan dengan hasil persentase lemak leher yang diperoleh Faber (2010) tentang penggunaan ekstrak alang-alang (Imperata cylindrical) untuk menurunkan penimbunan lemak pada broiler adalah $0,84-0,98 \%$ dan Rusydan (2008) tentang pengaruh penggunaan tepung akar alang-alang (Imperata cylindrical) terhadap penimbunan lemak pada broiler mendapatkan persentase lemak leher broiler yang berumur 42 hari adalah 0,080 0,109\%.

Perbedaan ini disinyalir disebabkan karena perbedaan umur potong yang dilakukan olah setiap peneliti. Siallagan (2011) penggunaan ekstrak daun katuk (Sauropus androgynous) dan minyak ikan lemuru plus vitamin $\mathrm{E}$ dalam ransum terhadap penimbunan lemak broiler mendapatkan persentase lemak leher ayam broiler berkisar antara $0,02 \%-0,08 \%$, dimana hasil penelitian ini sejalan dengan hasil penelitian yang dilakukan Siallagan (2011) dan hasil-hasil penelitian ini berpengaruh tidak nyata terhadap setiap perlakuan yang diberikan.

\section{Pengaruh pemberian limbah jintan hitam terhadap persentase lemak sartorial}

Hasil analisis ragam menunjukkan bahwa perlakuan pemberian limbah jintan hitam berpengaruh tidak nyata $(\mathrm{P}>0,05)$ terhadap lemak sartorial. Hal ini berarti bahwa limbah jintan hitam tidak dapat menurunkan lemak sartorial ayam broiler. Persentase lemak sartorial yang diperoleh selama penelitian $0,48 \% \quad-0,58 \%$. Jika dibandingkan dengan penelitian yang dilakukan oleh Putra (2014) persentase lemak sartorial ayam broiler berkisar $0,16 \%$ $0,19 \%$ dari berat hidup. Faber (2010) menemukan persentase lemak sartorial pada ayam broiler $0,64 \%$ - 0,74\%. Rusydan (2008) mendapatkan persentase lemak sartorial pada ayam broiler adalah $0,59 \%$ $0,78 \%$. 
Selanjutnya menurut Siallagan (2011) bahwa persentase lemak sartorial pada ayam broiler umur 42 hari adalah $0,16 \%-0,34 \%$. Berdasarkan data tersebut dapat disimpulkan bahwa lemak sartorial pada ayam broiler sangat bervariasi dan hasil-hasil penelitian ini berpengaruh tidak nyata terhadap setiap perlakuan yang diberikan.

\section{Kesimpulan}

\section{KESIMPULAN}

Dari hasil penelitian ini dapat disimpulkan bahwa pemberian limbah jintan hitam (Nigella sativa) dalam ransum tidak dapat menurunkan deposisi lemak ayam broiler.

\section{DAFTAR PUSTAKA}

Bidura, I. G. N. G, dan I. B. G. Pratama. 2010. Pengaruh penggunaan tepung bulu ayam terfermentasi dalam ransum terhadap bobot potong dan jumlah lemak abdomen ayam broiler. Majalah Ilmiah Peternakan. 13(3): 98-102.

El-Nattat, W. S. and R. I. El-Kady. 2007. Effect of different medicinal plant seeds residues on the nutritional and reproductive performance of adult male rabbits. International Journal of Agriculture \& Biology. 9(3) : 102116.

El-Rahman, Abd H.H., A.A. Abedo,Fatma M. Salman, M.I.Mohamed and M.M. Shoukry. 2011. Partial substitution of cumin seed meal by jatropha meal as a potential protein source for feed. African Journal of Biotechnology . 10 (68) : 15456-15461.

Faber, J. 2010. Penggunaan ekstrak akar alang-alang (Imperata cylindrical) untuk menurunkan penimbunan lemak pada broiler. Skripsi. Jurusan Peternakan Fakultas Pertanian Universitas Bengkulu. Bengkulu.
Fontana, E. A., D. Jr. Weaver, D. M. Denbaow and B. A. Watkins. 1993. Early feed restricition of broiler : Effect on abdominal fat pad, liver, and gizzard weight, fat deposition and carcass composition. Poult. Sci. 72: $243-250$.

Habi, A., S. Osfar, dan H. I. Djunaidi. 2014. Pengaruh penggunaan tepung jintan hitam (Nigella sativa) dalam pakan terhadap persentase karkas, organ dalam dan lemak abdominal itik hibrida. Artikel Ilmiah. Universitas Brawijaya. Malang.

Hartadi, H., S. Reksohadiprodjo dan A.D. Tillman. 2005. Tabel Komposisi Pakan untuk Indonesia. Gadjah Mada University Press. Yogyakarta.

North, O. M. 1984. Commercial Chicken Production Manual. Third ed. AVI Publishing Company. Inc. Wesport, Connecticut.

Putra, S. A. 2014. Pengaruh pemberian fermentasi tepung kulit pisang jantan dengan menggunakan (Neurospora crassa) terhadap deposisi lemak ayam broiler. Skripsi. Jurusan Peternakan Fakultas Pertanian Universitas Bengkulu. Bengkulu.

Rouhou, S. C., B. Souhail., H. Basma., B. Christophe., D. Calude and A. Hamadi. 2007. Nigella sativa L.: chemical composition and physicochemical characteristics of lipid fraction. Food Chem Journal 10: 673-681.

Rusydan, M. 2008. Pengaruh penggunaan tepung akar alang-alang (Imperata cylindrical) terhadap Penimbunan Lemak Pada Broiler. Skripsi. Jurusan Peternakan Fakultas Pertanian Universitas Bengkulu. Bengkulu.

Salama, R. H. M. 2010. Clinical and therapeutic trials of Nigella sativa. TAF Prev. Med. Bull. 9(5): 513-522. 
Salam, S. 2013. Berat karkas dan lemak abdominal ayam broiler yang diberi tepung jintan hitam (Nigella sativa) dalam ransum selama musim panas. Sains Peternakan. 11(2): 84-89.

Sandi, S. R. Palupi dan Amyesti. 2012. Pengaruh penambahan ampas tahu dan dedak fermentasi terhadap karkas, usus, dan lemak abdomen ayam broiler. Agrinak. 2:1-5.

Siallagan, J. 2011. Penggunaan ektrak daun katuk (Sauropus androgynous) dan minyak ikan lemuru plus vitamin E dalam ransum terhadap penimbunan lemak broiler. Skripsi. Jurusan Peternakn Fakultas Pertanian Universitas Bengkulu. Bengkulu.
Steel, R. G. D dan J. H. Torrie. 1993. Prinsip dan Prosedur Statistika. Suatu Pendekatan Biometrik. Terjemahan : M.Syah. PT.Gramedia.

Sutrisna, I. B., I. W. Sudiastra, dan I. G. Putra. 2001. Penambahan serbuk gergaji kayu, ragi tape, dalam kombinasinya dalam ransum basal distribusi lemak tubuh ayam pedaging. Majalah Ilmiah Peternakan. 5(2): 39-43.

Tumova, E. and A. Teimouri. 2010. Fat deposition in the broiler chicken: A review. Scientia Agriculturae Bohemica. 41(2): 121-128. 